\title{
Age and sex estimation using fractal analysis in Brazilian adults: a discriminant
}

\section{analysis}

\author{
Estimativa de idade e sexo por meio da análise fractal em adultos brasileiros: uma análise \\ discriminante
}

Estimación de edad y sexo mediante análisis fractal en adultos brasileños: un análisis discriminante

Fabrício dos Santos Menezes ORCID: https://orcid.org/0000-0001-9230-1879 University of São Paulo, Brazil Federal University of Sergipe, Brazil

E-mail: fabriciomenezes@msn.com

Társilla de Menezes Dinísio ORCID: https://orcid.org/0000-0002-6180-3339 Federal University of Sergipe, Brazil E-mail: tmdinisio@gmail.com

Thaís Feitosa Leitão de Oliveira ORCID: https://orcid.org/0000-0003-1953-7409

State University of Feira de Santana, Brazil

E-mail: thaisfeitosaoliveira@gmail.com

Ana Maria Braga de Oliveira ORCID: https://orcid.org/0000-0002-7718-9759 Federal University of Sergipe, Brazil E-mail: ana.fisio.6@hotmail.com

Claudio Costa

ORCID: https://orcid.org/0000-0003-2831-8670 University of São Paulo, Brazil E-mail: clacosta@usp.br

Edgard Michel-Crosato

ORCID: https://orcid.org/0000-0001-8559-9769 University of São Paulo, Brazil. E-mail: michelcrosato@usp.br

Maria Gabriela Haye Biazevic ORCID: https://orcid.org/0000-0001-6326-5805 University of São Paulo, Brazil E-mail: biazevic@usp.br

\begin{abstract}
This study assessed the accuracy of fractal analysis (FA) to estimate chronological age and sex in Brazilian adults for forensic investigations. The gender-balanced sample comprised lateral cephalometric radiographs of 120 individuals, stratified according to age (20-29, 30-39, 40-49, 50-59 years) and sex (female and male). A trained calibrated examiner measured the fractal dimension (FD) of the mandibular ramus and mandibular angle. Linear regression and multiple logistic discriminant analysis were carried out to explore the accuracy of FA. For all analyses, p-values $<.05$ indicated statistical significance. Overall, mean FD values were $1.49 \pm 0.10$ for the mandibular ramus and $1.48 \pm 0.09$ for mandibular angle. Results were more accurate in males than females for discriminating age and sex. The multiple discriminant analysis indicated that FA distinguished sex in $61.7 \%$ males and $58.3 \%$ females. In addition, the mean difference between actual and predicted value was 9.5 years and 10.1 years for men and women, respectively. Fractal analysis accurately identified sex- and age-related differences in the trabecular pattern of the mandible of Brazilian adults, confirming its utility for forensic investigations. Further studies investigating other populations are needed to assess the accuracy of FA for Forensic Dentistry.
\end{abstract}

Keywords: Forensic dentistry; Image processing, Computer-assisted; Age determination by skeleton; Sex determination analysis.

\section{Resumo}

Esse estudo avaliou a acurácia da análise fractal (FA) para estimar a idade cronológica e o sexo de adultos brasileiros para investigações forenses. A amostra balanceada envolveu as radiografias cefalométricas laterais de 120 indivíduos, que foram organizadas conforme o grupo etário (20-29, 30-39, 40-49, 50-59 anos) e o sexo (masculino e feminino). Todas as análises do ramo e do ângulo mandibular foram realizadas por um examinador treinado e calibrado. Para a 
estimativa da idade e do sexo, utilizaram-se a regressão linear e a análise discriminante logística múltipla. Adicionalmente, verificou-se a precisão da FA a partir da diferença absoluta entre a idade real e a idade predita. Para todas as análises, um p-valor < 0,05 indicou a significância estatística. No total, a média dos valores da dimensão

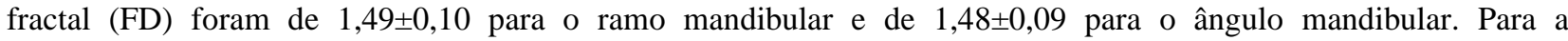
discriminação do sexo e da idade, os homens tiveram melhores resultados do que as mulheres. A análise discriminante múltipla indicou que a FA distingue o sexo em 61,7\% dos homens e 58,3\% das mulheres. Adicionalmente, a diferença média entre a idade real e a predita foi de 9,5 anos e 10,1 anos para o sexo masculino e feminino, respectivamente. Portanto, nós observamos que a FA identificou as mudanças no padrão do trabeculado ósseo mandibular aplicáveis para se estimar a idade cronológica e o sexo em adultos brasileiros. Estudos em outras populações são necessários para investigar a acurácia da FA para a Odontologia Forense.

Palavras-chave: Odontologia legal; Processamento de imagem assistida por computador; Determinação da idade pelo esqueleto; Análise para determinação do sexo.

\begin{abstract}
Resumen
Este estudio evaluó la precisión del análisis fractal (FA) para estimar la edad cronológica y el sexo en individuos adultos brasileños para investigaciones forenses. La muestra balanceada estuvo compuesta por radiografías cefalométricas laterales de 120 individuos, las cuales fueron organizadas según grupo de edad (20-29, 30-39, 40-49, 50-59 años) y sexo (femenino y masculino). Todas las análisis de la rama mandibular y del ángulo mandibular fueron realizadas por un examinador capacitado y calibrado. Para la estimación de edad y sexo, se utilizó regresión lineal y análisis discriminante logístico múltiple. En consecuencia, verificamos la precisión del FA midiendo las diferencias entre la edad pronosticada y la real. Para todas las análisis, un valor de $\mathrm{p}<0,05$ indicó la significancia estadística. En general, la media de los valores de la dimensión fractal (FD) fue 1,49 \pm 0,10 para la rama mandibular y 1,48 $\pm 0,09$ para el ángulo mandibular. En general, los hombres obtuvieron mejores resultados con el FA que las mujeres en la discriminación por edad y sexo. El análisis discriminante múltiple indicó que FA distingue el sexo en el 61,7\% de los hombres y el 58,3\% de las mujeres. Además, la diferencia media entre el valor real y el predicho fue de 9,5 años y 10,1 años para hombres y mujeres, respectivamente. Por lo tanto, observamos que FA es precisa para identificar cambios relacionados con el sexo y la edad en el patrón trabecular de la mandíbula de adultos brasileños en investigaciones forenses. Se necesitan más estudios que investiguen otras poblaciones para evaluar la precisión del FA para odontología forense.
\end{abstract}

Palabras clave: Odontología forense; Procesamiento de imagen asistido por computador; Determinación de la edad por el esqueleto; Análisis para determinación del sexo.

\title{
1. Introduction
}

Forensic Dentistry entails processing, reviewing, and assessing dental evidence to assist the legal system by providing scientific and objective data (Ata-Ali \& Ata-Ali, 2014). Forensic odontologists use dental findings and skeletonized skulls in legal cases to determine individuals' age, biotype, height, and sex (Andrade et al., 2021; Silva, 1997). Likewise, these professionals seek to establish the criminal responsibility and human identification in cases of missing persons (Angadi, Hemani, Prabhu, \& Acharya, 2013), mass disasters (Prajapati et al., 2018), and migratory phenomena (da Luz et al., 2019), among other examples.

Human identification consists of a branch of techniques to provide reliable information to aid experts concerning social issues of a criminal and civil nature. When use of DNA techniques is not possible, oral and maxillofacial characteristics serve as a suitable means of establishing individual identity (Divakar, 2017). In Forensic Dentistry, several techniques are available for establishing personal identification, such as cheiloscopy, human bites, rugoscopy, and the application of biomolecular methods for analyzing DNA from dental pulp tissue (Ata-Ali \& Ata-Ali, 2014; Gioster-Ramos, Silva, Nascimento, Fernandes, \& Serra, 2021). In forensic cases without previous records, age and sex are valuable parameters to support human identification. These techniques initially centered on the development of secondary dentin (Gustafson, 1950) with authors subsequently refining methods based on pulp cavity, contributing to minimally-invasive methods through dental imaging (Marroquin et al., 2017). In adults, these techniques have limitations due to the lack of differences in the rhizogenesis process and dental eruption chronology (Cunha \& Wasterlain, 2015). In parallel, populations are rapidly aging worldwide; hence, accurate proper methods for age estimation and sexual dimorphism in adulthood are crucial to support human identification services. 
In adults, human identification relies on anatomo-physiological alterations in dental, bone, and oral structures (Cunha \& Wasterlain, 2015). In this context, digital image processing allows the assessment of morphologic features of the trabecular bone pattern with minimally-invasive techniques, such as fractal analysis (FA) (Kato et al., 2019; White \& Rudolph, 1999). The word fractal originates from the word "fractus" meaning "broken" or "fractured" (Sanchez \& Uzcategui, 2011). This mathematical method was first described in 1897 and has since improved to encompass irregular and complex body regions (Geraets \& Van der Stelt, 2000; White \& Rudolph, 1999). Fractal geometry is a quantitative approach to characterize complex self-similar shapes using the fractal dimension (FD) (Sanchez \& Uzcategui, 2011), with $\mathrm{D}=\log \mathrm{n} / \log \varepsilon$, where $\mathrm{N}$ is the total of parts and $\varepsilon$ is the specified scale (Barcellos, 1984; Cross, 1997). In dentistry, this method has been used in endodontics (Chen et al., 2005; Uğur Aydın et al., 2019; Yu et al., 2009), implantology (Lee et al., 2010; Tözüm, Dursun, \& Uysal, 2016), orthodontics (Kwak, Kim, Kim, \& Kim, 2016), pathology (Cross, 1997), periodontics (Pârvu, Ţălu, Crăciun, \& Alb, 2014), and oral and maxillofacial surgery (Heo et al., 2002). There is enough evidence supporting the application of FA in Dentistry (Kato et al., 2019; Sanchez \& Uzcategui, 2011), but data on its application in forensic analysis remains scarce.

Identification is one the central tasks of Forensic Dentistry (Ohtani \& Yamamoto, 2010), that depends on accurate, feasible, and low-cost techniques for use mainly in adults (Cunha \& Wasterlain, 2015; Marroquin et al., 2017). In parallel, fractals may be temporal or spatial on infinite scales and involve repeating patterns (Kato et al., 2019), and age-related alterations in alveolar bone have been observed in postmenopausal females (Ruttimann, Webber, \& Hazelrig, 1992). Furthermore, researchers have identified changes in the FD values in the brain white matter of the brain due to aging and sex (Farahibozorg, Hashemi-Golpayegani, \& Ashburner, 2015). We hypothesized that alterations in the morphology of the trabecular bone of the mandible occur over time, changes which may be identified in lateral cephalometric radiographs. Therefore, this study aimed to investigate the accuracy of FA to estimate chronological age and sex in Brazilian adults for forensic investigations.

\section{Methodology}

This is a diagnostic accuracy study for forensic purposes using fractal dimension (FD) measurements. The balanced sample comprised 120 lateral cephalometric radiographs performed for previous treatments between March 2016 and March 2021. We collected records from a private radiology clinic database in Bahia, Brazil, ensuring the privacy of individuals' identities. Therefore, we assembled 15 individuals into eight groups according to the age group (20-29, 30-39, 40-49, 50-59 years old) and sex (female and male). The Research Ethics Committee of the School of Dentistry of the University of São Paulo (FOUSP) approved the study (process number 4.496.135). The investigation observed the ethical standards for research involving humans defined by the Helsinki Declaration and Brazilian legislation.

The present series included cephalometric radiographs of adult individuals aged $\geq 20$ years at the time of radiographic examination, for which information was extracted on sex, date of birth, and date of radiograph examination. Date of birth was subtracted from date of radiograph to determine chronological age. Exclusion criteria were low-quality radiographs (i.e., elongated and/or blurring X-rays and images presenting overlaps and distortion of bone structures) which were not eligible for digital processing. Moreover, any morphologic alterations in trabecular bone in the regions of interest (ROIs), such as the presence of lesions, were excluded.

All dental images were acquired using the same device (Orthophos SL 3D, Dentsply Sirona, Bensheim, Germany; 60$80 \mathrm{kVp}, 9 \mathrm{~mA}, 17.6$-s exposure time). Patients were positioned according to the manufacturer's endorsements, i.e., the Frankfurt horizontal plane was parallel to the floor and patient's sagittal plane was aligned with the vertical line produced by the machine. The examiner analyzed radiographs, which were in [.jpg] format with at least 244 dpi of resolution (1,804 x 2,148 pixels) using ImageJ version 1.52a software (National Institutes of Health, Bethesda, MD, USA) using a notebook computer 
(NP760XBE-XW1BR, Samsung, Brazil), with a 64-in, connected to a 28-inch LCD screen with a resolution of $1366 \times 768$ pixels.

For digital image processing, two ROIs measuring 64 x 64 pixels were selected within the trabecular bone (Kato et al., 2019). ROI1 and ROI2 were specified as the geometric center of the mandibular angle and ramus, respectively (Coşgunarslan, Canger, Soydan Çabuk, \& Kış, 2020) (Figure 1). The FA was carried out using the box-counting method (White \& Rudolph, 1999). For the measurement of fractal dimension (FD), the examiner performed the following steps: (i) selection of ROIs (64x64 pixels) (Figure 2.A); (ii) duplication of ROIs (Figure 2.B); (iii) use of Gaussian or gray filter (sigma: 35 pixels) (Figure 2.C); (iv) subtraction of blurred image from original (Figure 2.D); (v) addition of greyscale value of 128 (Figure 2.E); (vi) binary image (Figure 2.F); (vii) erosion of image (Figure 2.G); (viii) dilation of image (Figure 2.H); (ix) inversion of image (Figure 2.I); and (x) skeletonization of image (Figure 2.J) to assess FD using fractal box-counting method dividing image into box sizes of 2, 3, 4, 6, 8, 12, 16, 32 and 64 pixels (White \& Rudolph, 1999) (Figure 2).

Figure 1. Selection of the ROIs of $64 \times 64$ pixels in a cephalometric radiograph using ImageJ software.
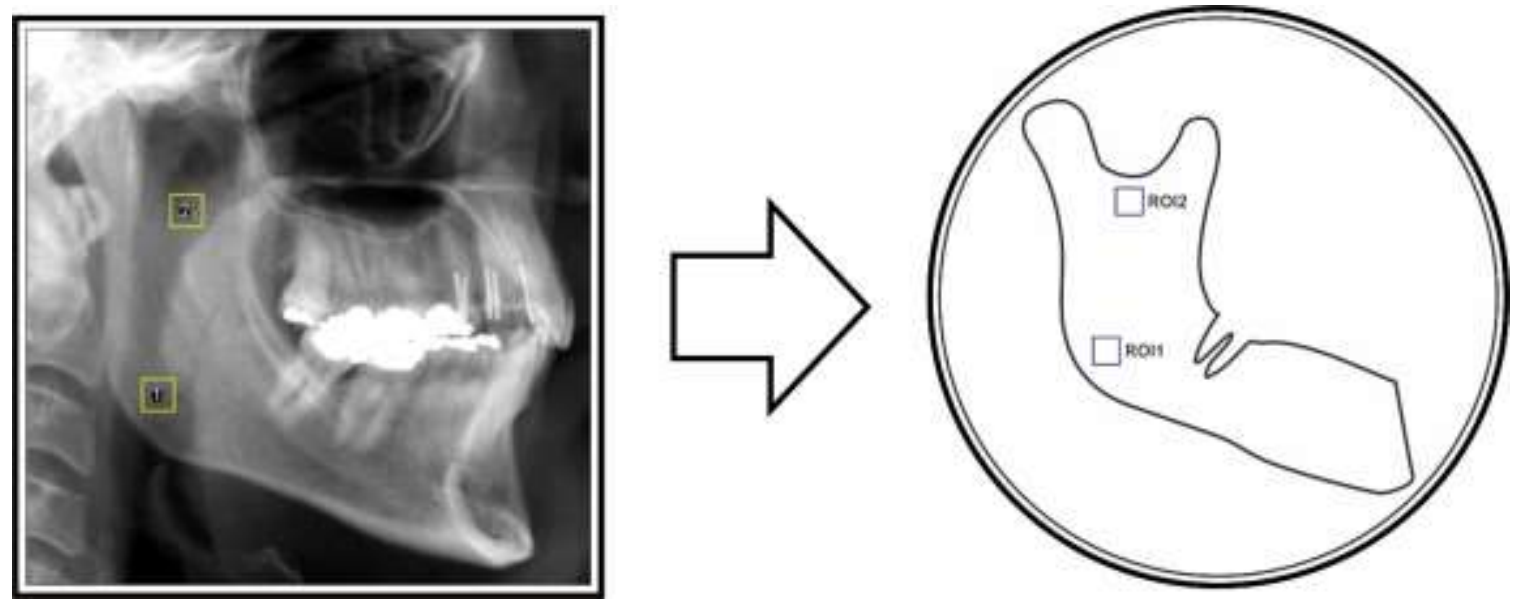

Source: Authors.

A single examiner (FSM) was trained and calibrated to ensure the reliability of the technique. Intra-examiner agreement was analyzed with $20 \%$ of the sample during a 2 -week interval using the Intraclass Correlation Coefficient (ICC). For all analysis, the examiner was blinded to the individuals' sex and chronological age.

For the descriptive analysis, the sample was expressed as frequencies, percentages, mean, and median and depicted using box plots by sex. The Shapiro-Wilk test and Levene's test were employed to assess normality and homoscedasticity, respectively. Student's t-test and the Mann-Whitney U-test were used to compare FD values for sex.

For age estimation, the association between FD measurements and age was investigated using linear regression. Based on the results, a formula was devised testing accuracy by assessing differences between predicted and actual age. Multiple logistic discriminant analysis was employed for sex estimation. A prior of $50 \%$ was set, given that sex is a dichotomous variable for which males and females have an equal probability of correct sex discrimination.

All statistical analyses were conducted using Stata software, version 17.0 (Stata Corporation, College Station, Texas, USA). The hypothesis tests were two-sided, and p-values $<.05$ indicated statistical significance. The dental imaging professionals (CC and TFLO) and the statistician (EMC) provided methodological support. 
Figure 2. Digital processing sequence for FD assessment.

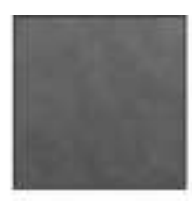

(A)

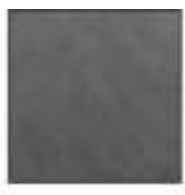

(B)

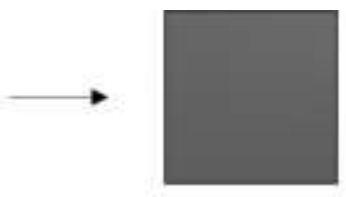

(C)

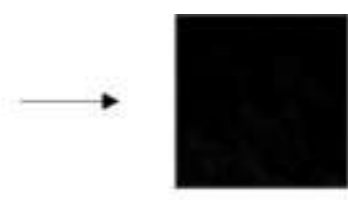

(D)

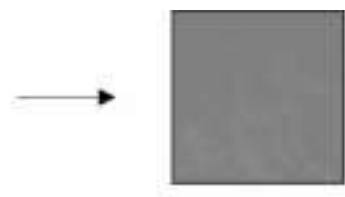

( $E)$

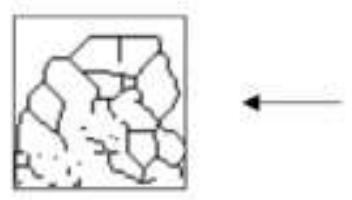

(J)

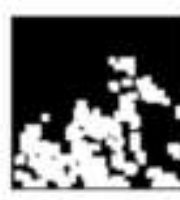

(1)
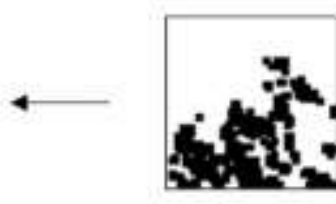

(H)
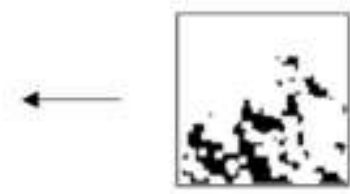

(G)

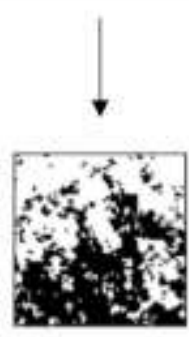

(F)

Source: Authors.

\section{Results}

In the present study, the measurements taken by the calibrated single examiner exhibited high reliability, with an ICC of 0.87 and 0.94 for mandibular ramus and mandibular angle, respectively. Overall, the study involved 120 individuals with a mean age of 38.5 years $( \pm 11.17)$, range 21-59 years. The balanced sample comprised 60 females and 60 males with mean ages of 38.8 years $( \pm 11.26)$ and 38.3 years $( \pm 11.17)$, respectively. Mean of the FD values were $1.49 \pm 0.10$ for mandibular ramus and $1.48 \pm 0.09$ for mandibular angle. For both regions of interest, the average of the FD values was higher for males than females (Table 1) (Figure 3).

Although no sex difference in mean FD was found (Table 2), discriminant logistic regression indicated that FD distinguished sex in $61.7 \%$ of males and $58.3 \%$ of females (Table 3 ).

Table 1. Descriptive analysis of FD values by ROI and sex.

\begin{tabular}{lcccccc}
\hline & N & Mean & Median & SD & Minimum & Maximum \\
\hline Mandibular ramus & & & & & & \\
$\quad$ Total & 120 & 1.49 & 1.50 & 0.10 & 1.28 & 1.68 \\
Female & 60 & 1.48 & 1.48 & 0.10 & 1.28 & 1.68 \\
$\quad$ Male & 60 & 1.50 & 1.52 & 0.09 & 1.32 & 1.63 \\
Mandibular angle & & & & & & \\
$\quad$ Total & 120 & 1.48 & 1.47 & 0.09 & 1.31 & 1.71 \\
Female & 60 & 1.47 & 1.45 & 0.08 & 1.31 & 1.68 \\
Male & 60 & 1.49 & 1.51 & 0.10 & 1.31 & 1.71 \\
\hline & SD: Standard deviation. Source: Authors. & &
\end{tabular}


Figure 3. FD values by ROI and sex.
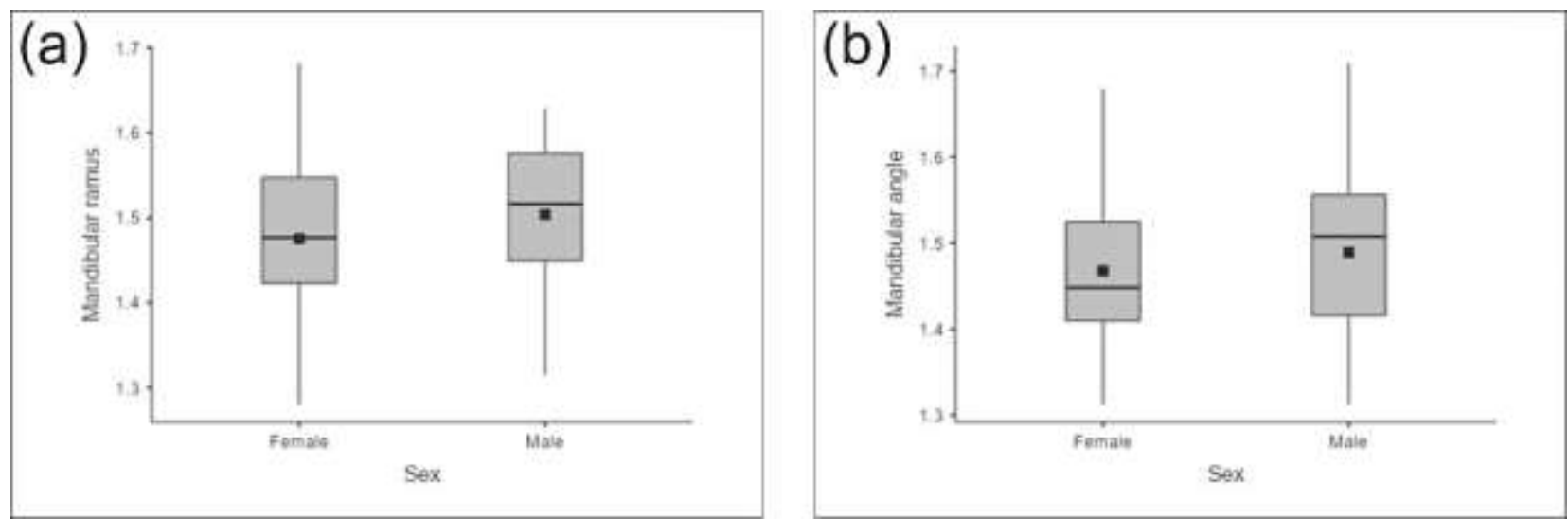

Source: Authors.

Table 2. Differences in FD values by ROI and sex.

\begin{tabular}{|c|c|c|c|c|c|c|c|c|}
\hline & Statistical test & Statistic & df & p-value & $\begin{array}{c}\text { Mean } \\
\text { difference }\end{array}$ & $\begin{array}{c}\text { SE } \\
\text { difference }\end{array}$ & $\begin{array}{l}\text { Shapiro- } \\
\text { Wilk }\end{array}$ & $\begin{array}{c}\text { Levene's } \\
\text { test }\end{array}$ \\
\hline \multicolumn{9}{|l|}{$\begin{array}{c}\text { Mandibular } \\
\text { ramus }\end{array}$} \\
\hline & Student's t & -1.65 & 118 & 0.102 & -0.0285 & 0.0173 & 0.027 & 0.272 \\
\hline & Mann-Whitney U & 1483 & & 0.097 & -0.0316 & & & \\
\hline \multicolumn{9}{|l|}{$\begin{array}{c}\text { Mandibular } \\
\text { angle }\end{array}$} \\
\hline & $\underline{\text { Student's t }}$ & -1.31 & 118 & 0.192 & -0.0214 & 0.0163 & 0.367 & 0.163 \\
\hline & Mann-Whitney U & 1535 & & 0.164 & -0.0245 & & & \\
\hline
\end{tabular}

df: degrees-of-freedom. * We carried out Student's t-test and Mann-Whitney U test due to the Shapiro-Wilk and Levene's test results. Source: Authors.

Table 3. Discriminant logistic regression using FD values*.

\begin{tabular}{|c|c|c|c|}
\hline & Female $^{\dagger}$ & Male $^{\dagger}$ & Total $^{\dagger}$ \\
\hline Female & $35(58.3)$ & $25(41.7)$ & $60(100.0)$ \\
\hline Male & $23(38.3)$ & $37(61.7)$ & $60(100.0)$ \\
\hline Total & $58(48.3)$ & $62(51.7)$ & $120(100.0)$ \\
\hline
\end{tabular}

Based on the FD values in mandibular ramus and mandibular angle, we carried out the linear regression model to describe the formula for age estimation in adults (Table 4). The formula for age estimation using the FD values was expressed as follows: age (years) $=58.08+$ FD value in mandibular ramus*(-1.824) + FD value in mandibular angle*(-11.316). Therefore, the mean difference between the actual and predicted values was 10.1 years for females and 9.5 years for males (Figure 4). 
Table 4. Linear regression model using FD values for age estimation in adults.

\begin{tabular}{|c|c|c|c|c|}
\hline & Estimate & SE & $\mathbf{t}$ & p-value \\
\hline Intercept $^{\mathrm{a}}$ & 58.083 & 19.66 & 2.954 & 0.004 \\
\hline Mandibular ramus & -1.824 & 12.12 & -0.15 & 0.881 \\
\hline Mandibular angle & -11.316 & 12.87 & -0.879 & 0.381 \\
\hline \multicolumn{5}{|c|}{ Model Fit Measures } \\
\hline & $\mathbf{R}^{2}$ & Adjusted R ${ }^{2}$ & AIC & RMSE \\
\hline & 0.0101 & -0.0155 & 927 & 11.1 \\
\hline
\end{tabular}

Figure 4. Differences between real and predicted age by sex.

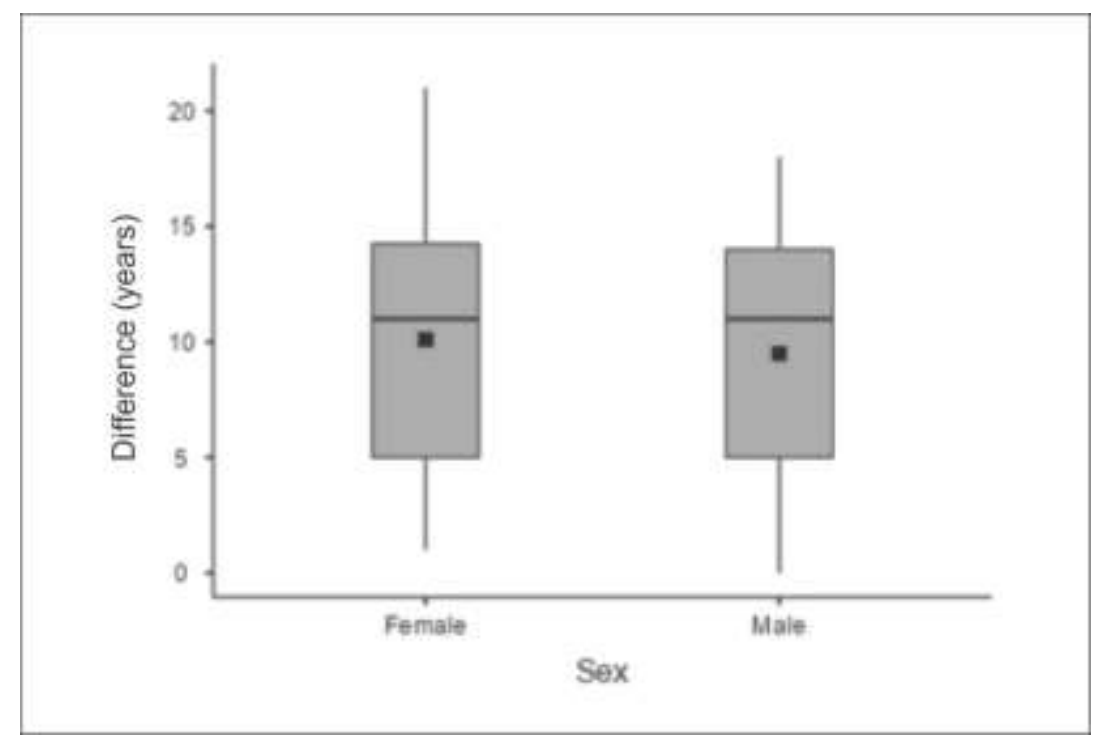

Source: Authors.

\section{Discussion}

This is the first study to report the accuracy of FA for age and sex estimation spanning adulthood using cephalometric radiographs. The results showed that FA in the mandibular ramus and mandibular angle provided acceptable sexual discriminant accuracy in association with other forensic methods. Measurements of FD values in cephalometric radiographs constitute a low-cost nondestructive minimally-invasive technique for human identification services. Thus, our data revealed that FA is useful to support experts for age and sex estimation in Brazilian adults, revealing the potential of digital imaging processing for forensic purposes.

Fractals contrast with conventional geometry in that they are temporal or spatial of infinite size and repeated shapes (Kato et al., 2019). Previous studies have identified the potential of FA for identifying age-related alterations in bone density (Ruttimann et al., 1992), corroborated by our findings. Moreover, FD values in the global and hemispheric white matter have revealed sex differences (Farahibozorg et al., 2015). Based on these aspects, it is reasonable to hypothesize that our findings are biologically plausible, supporting the utility of the technique for forensic investigations.

Digital processing of bone structures produces evidence for analysis in forensic practice without the destruction of bone or dental tissues. In parallel, FA is an easy low-cost method for estimating bone density (Otis, Hong, \& Tuncay, 2004). Although digital images have limitations in screen resolution, cephalometric x-rays offer advantages over other types of dental images, such as reduced dose ionizing radiation, low distortion, and real-size images (Kato et al., 2019). The current findings showed that FA is a nondestructive, reproducible, and reliable technique, which may be applicable for living adult individuals. 
In adults, age and sex estimation using dental images poses a challenge for forensic dentists. Nondestructive techniques have limitations because growing is well-known than aging. For instance, children and adolescents present several age-related anatomo-physiological alterations useful for forensic experts (e.g., rhizogenesis and dental eruption chronology); however, in adults, these multifactorial changes are absent or less observed. Accordingly, the older the age, the higher the standard error in measurements (Cunha \& Wasterlain, 2015). Despite these disadvantages, several methods have been developed for forensic investigations in adulthood based on dental imaging assessment, such as those of Cameriere (Azevedo et al., 2015; Cameriere, Ferrante, \& Cingolani, 2004), Gustafson (Gustafson, 1950), Kvaal \& Solheim (Kvaal, Kolltveit, Thomsen, \& Solheim, 1995), Kvaal (Kvaal et al., 1995), and Lamendin (Lamendin et al., 1992). For age estimation, our finding is similar to results of previous research, showing a mean error between actual and estimated age of about ten years (Lamendin et al., 1992). In adults, authors reported an accuracy of around three years for age estimation using teeth; nevertheless, this destructive technique uses the racemization of aspartic acid (Ohtani \& Yamamoto, 2010), in contrast with the nondestructive properties of the FA method.

The measurements of the FD values in mandibular ramus and angle allow the sex estimation in adults. In sexual dimorphism, adult mandibles may play a crucial role due to their dimorphic characteristics, resistance to injuries, and disintegration circumstances (Okkesim \& Sezen Erhamza, 2020; Sairam, Geethamalika, Kumar, Naresh, \& Raju, 2016). High sexual discriminant accuracy using the mandible has been reported for several methods (Dong et al., 2015; Hazari, Hazari, Mishra, Agrawal, \& Yadav, 2016; Lopez Capp, Paiva, Buscatti, Michel Crosato, \& Biazevic, 2021). Similarly, 87.5\% of studies found significant results for discriminating sex (Hazari et al., 2016). In the present study, the technique proved accurate for correctly identifying males than females. Moreover, the results were better than for other research in adults, which identified the prediction accuracy of $48.3 \%$ for males (Suazo Galdames et al., 2008). Although we found a discrete accuracy of FA in sexual dimorphism, this minimally-invasive technique is suitable for forensic investigations when associated with other methods to improve results in sex estimation.

This study has some limitations that should be considered. The FD values are influenced by factors such as systemic disease, which modifies the trabecular pattern (White \& Rudolph, 1999), as well as tobacco use (Basavarajappa, Konddajji Ramachandra, \& Kumar, 2021). In the present study, this information was absent in the records because radiology clinics do not routinely collect these data. However, previous studies using FA to investigate dental and bone alterations have found consistent results for the method (Pârvu et al., 2014; Soltani et al., 2021; Tözüm et al., 2016; Uğur Aydın et al., 2019; Yu et al., 2009). Moreover, a systematic review of publications on FA reported similar findings for range of FD values using the boxcounting method to those of the present study (Kato et al., 2019).

This study has several strengths with implications for forensic practice, such as the use of cephalometric X-rays and its convenience and costs for age and sex estimation. Furthermore, FA is an easy, quantitative, and minimally-invasive digital imaging procedure requiring only expert training with no software expenses. Although this technique was used in living adults, it may be applicable for use in deceased individuals without complete dry skulls; nevertheless future studies should address this application and validate its accuracy. Further investigations assessing diverse populations are required to evaluate the accuracy of FA for age and sex estimation. However, FA is a useful tool for forensic investigations given its accuracy for distinguishing sex and predicting age in Brazilian individuals. Therefore, it can be concluded that FA represents an auxiliary digital imaging processing tool that can aid experts in future forensic investigations in adults.

\section{Conclusion}

Fractal analysis is a simple, reproducible, and reliable digital image processing technique for assessing chronological age and sex in cephalometric radiographs in Brazilian adults. Overall, FA was more accurate for identifying males than 
females in the mandibular ramus and mandibular angle. The accuracy percentage was $61.7 \%$ for males and $58.3 \%$ for females, whereas the discriminant formula showed an average difference between the real- and predicted values of 9.5 years and 10.1 years, respectively. Therefore, FA proved a suitable supplementary technique for aiding experts in age and sex estimation in Brazilian adults. Further studies investigating other populations are needed to assess the accuracy of FA for Forensic Dentistry.

\section{Acknowledgments}

We extend our thanks to the Federal University of Sergipe for supporting FSM as a postdoctoral researcher at the School of Dentistry of the University of São Paulo (FOUSP). Also, we thank the Laboratory of Analysis and Image Processing (LAPI) of the FOUSP for providing the image database for the FA training.

\section{References}

Andrade, A. M. da C., Gomes, J. de A., Oliveira, L. K. B. F., Santos, L. R. S., Silva, S. R. C. da, Moura, V. S. de, \& Romão, D. A. (2021). Legal dentistry the role of the Odontolegist in the identification of cadaveres: an integrating review. Research, Society and Development, 10(2 SE-), e29210212465. https://doi.org/10.33448/rsd-v10i2.12465

Angadi, P. V, Hemani, S., Prabhu, S., \& Acharya, A. B. (2013). Analyses of odontometric sexual dimorphism and sex assessment accuracy on a large sample. Journal of Forensic and Legal Medicine, 20(6), 673-677. https://doi.org/10.1016/j.jflm.2013.03.040

Ata-Ali, J., \& Ata-Ali, F. (2014). Forensic dentistry in human identification: A review of the literature. Journal of Clinical and Experimental Dentistry, 6(2), e162-7. https://doi.org/10.4317/jced.51387

Azevedo, A. de C. S., Alves, N. Z., Michel-Crosato, E., Rocha, M., Cameriere, R., \& Biazevic, M. G. H. (2015). Dental age estimation in a Brazilian adult population using Cameriere's method. Brazilian Oral Research, 29. https://doi.org/10.1590/1807-3107BOR-2015.vol29.0016

Barcellos, A. (1984). The fractal geometry of Mandelbrot. The Two-Year College Mathematics Journal, 15(2), 98-114.

Basavarajappa, S., Konddajji Ramachandra, V., \& Kumar, S. (2021). Fractal dimension and lacunarity analysis of mandibular bone on digital panoramic radiographs of tobacco users. Journal of Dental Research, Dental Clinics, Dental Prospects, 15(2), 140-146. https://doi.org/10.34172/joddd.2021.024

Cameriere, R., Ferrante, L., \& Cingolani, M. (2004). Variations in pulp/tooth area ratio as an indicator of age: a preliminary study. Journal of Forensic Sciences, 49(2), 317-319.

Chen, S.-K., Oviir, T., Lin, C.-H., Leu, L.-J., Cho, B.-H., \& Hollender, L. (2005). Digital imaging analysis with mathematical morphology and fractal dimension for evaluation of periapical lesions following endodontic treatment. Oral Surgery, Oral Medicine, Oral Pathology, Oral Radiology, and Endodontics, 100(4), 467-472. https://doi.org/10.1016/j.tripleo.2005.05.075

Coşgunarslan, A., Canger, E. M., Soydan Çabuk, D., \& Kış, H. C. (2020). The evaluation of the mandibular bone structure changes related to lactation with fractal analysis. Oral Radiology, 36(3), 238-247. https://doi.org/10.1007/s11282-019-00400-6

Cross, S. S. (1997). Fractals in pathology. The Journal of Pathology, 182(1), 1-8.

Cunha, E., \& Wasterlain, S. (2015). Estimativa da idade por métodos dentários. In Estimativa da idade por métodos dentários. Coimbra: Imprensa da Universidade de Coimbra.

da Luz, L. C. P., Anzulović, D., Benedicto, E. N., Galić, I., Brkić, H., \& Biazevic, M. G. H. (2019). Accuracy of four dental age estimation methodologies in Brazilian and Croatian children. Science \& Justice, 59(4), 442-447. https://doi.org/https://doi.org/10.1016/j.scijus.2019.02.005

Divakar, K. P. (2017). Forensic Odontology: The New Dimension in Dental Analysis. International Journal of Biomedical Science : IJBS, 13(1), 1-5.

Dong, H., Deng, M., Wang, W., Zhang, J., Mu, J., \& Zhu, G. (2015). Sexual dimorphism of the mandible in a contemporary Chinese Han population. Forensic Science International, 255, 9-15. https://doi.org/10.1016/j.forsciint.2015.06.010

Farahibozorg, S., Hashemi-Golpayegani, S. M., \& Ashburner, J. (2015). Age- and sex-related variations in the brain white matter fractal dimension throughout adulthood: an MRI study. Clinical Neuroradiology, 25(1), 19-32. https://doi.org/10.1007/s00062-013-0273-3

Geraets, W. G., \& Van der Stelt, P. F. (2000). Fractal properties of bone. Dentomaxillofacial Radiology, 29(3), 144-153.

Gioster-Ramos, M., Silva, E., Nascimento, C., Fernandes, C., \& Serra, M. (2021). Técnicas de identificação humana em Odontologia Legal. Research, Society and Development, 10, e20310313200. https://doi.org/10.33448/rsd-v10i3.13200

Gustafson, G. (1950). Age determination on teeth. Journal of the American Dental Association (1939), 41(1), 45-54. https://doi.org/10.14219/jada.archive.1950.0132

Hazari, P., Hazari, R. S., Mishra, S. K., Agrawal, S., \& Yadav, M. (2016). Is there enough evidence so that mandible can be used as a tool for sex dimorphism? A systematic review. Journal of Forensic Dental Sciences, 8(3), 174. https://doi.org/10.4103/0975-1475.195111 
Heo, M.-S., Park, K.-S., Lee, S.-S., Choi, S.-C., Koak, J.-Y., Heo, S.-J., \& Kim, J.-D. (2002). Fractal analysis of mandibular bony healing after orthognathic surgery. Oral Surgery, Oral Medicine, Oral Pathology, Oral Radiology, and Endodontics, 94(6), 763-767. https://doi.org/10.1067/moe.2002.128972

Kato, C. N., Barra, S. G., Tavares, N. P., Amaral, T. M., Brasileiro, C. B., Mesquita, R. A., \& Abreu, L. G. (2019). Use of fractal analysis in dental images: a systematic review. Dento Maxillo Facial Radiology, 20180457. https://doi.org/10.1259/dmfr.20180457

Kvaal, S. I., Kolltveit, K. M., Thomsen, I. O., \& Solheim, T. (1995). Age estimation of adults from dental radiographs. Forensic Science International, 74(3), 175-185. https://doi.org/10.1016/0379-0738(95)01760-g

Kwak, K. H., Kim, S. S., Kim, Y.-I., \& Kim, Y.-D. (2016). Quantitative evaluation of midpalatal suture maturation via fractal analysis. Korean Journal of Orthodontics, 46(5), 323-330. https://doi.org/10.4041/kjod.2016.46.5.323

Lamendin, H., Baccino, E., Humbert, J. F., Tavernier, J. C., Nossintchouk, R. M., \& Zerilli, A. (1992). A simple technique for age estimation in adult corpses: the two criteria dental method. Journal of Forensic Sciences, 37(5), 1373-1379.

Lee, D.-H., Ku, Y., Rhyu, I.-C., Hong, J.-U., Lee, C.-W., Heo, M.-S., \& Huh, K.-H. (2010). A clinical study of alveolar bone quality using the fractal dimension and the implant stability quotient. Journal of Periodontal \& Implant Science, 40(1), 19-24. https://doi.org/10.5051/jpis.2010.40.1.19

Lopez Capp, T. T., Paiva, L. A. S. de, Buscatti, M. Y., Michel Crosato, E., \& Biazevic, M. G. H. (2021). Sex estimation of Brazilian skulls using discriminant analysis of cranial measurements. Research, Society and Development, 10(10 SE-), e266101018760. https://doi.org/10.33448/rsd-v10i10.18760

Marroquin, T. Y., Karkhanis, S., Kvaal, S. I., Vasudavan, S., Kruger, E., \& Tennant, M. (2017). Age estimation in adults by dental imaging assessment systematic review. Forensic Science International, 275, 203-211. https://doi.org/10.1016/j.forsciint.2017.03.007

Ohtani, S., \& Yamamoto, T. (2010). Age estimation by amino acid racemization in human teeth. Journal of Forensic Sciences, 55(6), 1630-1633. https://doi.org/10.1111/j.1556-4029.2010.01472.x

Okkesim, A., \& Sezen Erhamza, T. (2020). Assessment of mandibular ramus for sex determination: Retrospective study. Journal of Oral Biology and Craniofacial Research, 10(4), 569-572. https://doi.org/10.1016/j.jobcr.2020.07.019

Otis, L. L., Hong, J. S. H., \& Tuncay, O. C. (2004). Bone structure effect on root resorption. Orthodontics \& Craniofacial Research, 7(3), 165-177. https://doi.org/https://doi.org/10.1111/j.1601-6343.2004.00282.x

Pârvu, A. E., Ţălu, Ş., Crăciun, C., \& Alb, S. F. (2014). Evaluation of scaling and root planing effect in generalized chronic periodontitis by fractal and multifractal analysis. Journal of Periodontal Research, 49(2), 186-196. https://doi.org/10.1111/jre.12093

Prajapati, G., Sarode, S. C., Sarode, G. S., Shelke, P., Awan, K. H., \& Patil, S. (2018). Role of forensic odontology in the identification of victims of major mass disasters across the world: A systematic review. PloS One, 13(6), e0199791. https://doi.org/10.1371/journal.pone.0199791

Ruttimann, U. E., Webber, R. L., \& Hazelrig, J. B. (1992). Fractal dimension from radiographs of peridental alveolar bone. A possible diagnostic indicator of osteoporosis. Oral Surgery, Oral Medicine, and Oral Pathology, 74(1), 98-110.

Sairam, V., Geethamalika, M. V, Kumar, P. B., Naresh, G., \& Raju, G. P. (2016). Determination of sexual dimorphism in humans by measurements of mandible on digital panoramic radiograph. Contemporary Clinical Dentistry, 7(4), 434-439. https://doi.org/10.4103/0976-237X.194110

Sanchez, I., \& Uzcategui, G. (2011). Fractals in dentistry. Journal of Dentistry, 39(4), 273-292. https://doi.org/10.1016/j.jdent.2011.01.010

Silva, M. (1997). Compêndio de odontologia legal. Rio de Janeiro, RJ: MEDSI.

Soltani, P., Sami, S., Yaghini, J., Golkar, E., Riccitiello, F., \& Spagnuolo, G. (2021). Application of Fractal Analysis in Detecting Trabecular Bone Changes in Periapical Radiograph of Patients with Periodontitis. International Journal of Dentistry, 2021, 3221448. https://doi.org/10.1155/2021/3221448

Suazo Galdames, I. C., San Pedro Valenzuela, J., Schilling Quezada, N. A., Celis Contreras, C. E., Hidalgo Rivas, J. A., \& Cantín López, M. (2008). Ortopantomographic Blind Test of Mandibular Ramus Flexure as a Morphological Indicator of Sex in Chilean Young Adults. International Journal of Morphology, vol. 26, pp. 89-92.

Tözüm, T. F., Dursun, E., \& Uysal, S. (2016). Radiographic Fractal and Clinical Resonance Frequency Analyses of Posterior Mandibular Dental Implants: Their Possible Association With Mandibular Cortical Index With 12-Month Follow-up. Implant Dentistry, 25(6), 789-795. https://doi.org/10.1097/ID.0000000000000496

Uğur Aydın, Z., Toptaş, O., Göller Bulut, D., Akay, N., Kara, T., \& Akbulut, N. (2019). Effects of root-end filling on the fractal dimension of the periapical bone after periapical surgery: retrospective study. Clinical Oral Investigations, 23(9), 3645-3651. https://doi.org/10.1007/s00784-019-02967-0

White, S. C., \& Rudolph, D. J. (1999). Alterations of the trabecular pattern of the jaws in patients with osteoporosis. Oral Surgery, Oral Medicine, Oral Pathology, Oral Radiology, and Endodontics, 88(5), 628-635. https://doi.org/10.1016/s1079-2104(99)70097-1

Yu, Y.-Y., Chen, H., Lin, C.-H., Chen, C.-M., Oviir, T., Chen, S.-K., \& Hollender, L. (2009). Fractal dimension analysis of periapical reactive bone in response to root canal treatment. Oral Surgery, Oral Medicine, Oral Pathology, Oral Radiology, and Endodontics, 107(2), 283-288. https://doi.org/10.1016/j.tripleo.2008.05.047 